American Journal of Environmental Sciences 3 (4): 193-198, 2007

ISSN 1553-345X

(C) 2007 Science Publications

\title{
Detoxification of Heavy Metal Contaminated Soils
}

\author{
Floarea Damian and Gheorghe Damian \\ Department of Geology, North University of Baia Mare, \\ 62/A Dr. Victor Babes Street, 430083 Baia Mare, Romania
}

\begin{abstract}
The concentration of the heavy metals in the soils from the strong affected zones because of the mining and metallurgical industry, Baia Mare and Zlatna (Romania), is significant due to the high values of the contents and association of the four metals $\mathrm{Pb}, \mathrm{Cu}, \mathrm{Zn}, \mathrm{Cd}$. The efficacy of the natural zeolites in heavy metals immobilization from the studied soils was evaluated in experiments in which the plant growth was observed. Heavy metals contaminated soils have been treated with a mixture of organic substance and zeolites (organo - zeolitic material). Zeolitic tuffs were roll-crushed and ground in small grains with dimensions between 0.05 and $2.0 \mathrm{~mm}$. Clinoptilolite is the predominant zeolite and appears as compact masses of tabular and prismatic micron - sized crystals that are evident in SEM images. In the mixture, the polluted soil represents $83 \%$ and the organo - zeolitic material represents $17 \%$. The soils used in the experiment are excessive contaminated with $\mathrm{Pb}(40375-$ $1054 \mathrm{ppm})$ in association with $\mathrm{Zn}(1175-490 \mathrm{ppm}), \mathrm{Cd}(24.2-13.2 \mathrm{ppm})$ and $\mathrm{Cu}(409.5-37.6 \mathrm{ppm})$ in Baia Mare zone and with $\mathrm{Cu}$ (7000-360ppm) in association with $\mathrm{Zn}$ (3100-1900ppm), Cd (80-40ppm) and $\mathrm{Pb}(2000-50 \mathrm{ppm})$ in Zlatna zone. The original soil and the treated soil have been planted with Lolium perenne. The growth of the plants has demonstrated that the soil treated with organo-zeolitic material allows the growth of vegetation much faster than the original soil. These results show that growth of the plants was possible because the organo-zeolitic material mixed with the soil provides the substances necessary for the plants to develop (ammonium, humus, potassium, calcium). At the same time, heavy metals that inhibit the plant development are blocked through the cationic exchange mechanism that makes them enter the zeolites structure and they no longer directly have access to the plant roots
\end{abstract}

Keywords: soil polluted, organo-zeolitic, plant growth

\section{INTRODUCTION}

The soils polluted with heavy metals from the affected zones by the mining and metallurgical industry are strongly degraded (eroded), without vegetation and structure. The high level of pollution with the heavy metals in the soils around the mining and metallurgical complexes, the extension of the polluted areas and the mobilization of some metals on the soil profile, require to apply some remediation methods.

The concentration of the heavy metals in different soil types from the two areas, Baia Mare and Zlatna, vary on the soil profile until $1 \mathrm{~m}$ depth. Within the experiments there have been used different amendments for the heavy metal polluted soils, in order to allow plant growth and to reduce the negative impact upon the environment.

The zeolitic tuffs are used in a wide range of activities ${ }^{[1]}$ which has drawn attention upon their great potential regarding the industrial uses. During the last 40 years, many research studies were carried out concerning the use of the natural zeolites in many areas of activity including environmental protection ${ }^{[2]}$. The retaining and cationic exchange properties of the natural zeolites (clinoptilolite, chabasite, and phillipsite) have represented the base of their use in order to immobilize heavy metals in the soils ${ }^{[3]}$. Heavy metals $(\mathrm{Cu}, \mathrm{Pb}, \mathrm{Zn}$, and $\mathrm{Cd})$ can be retained by the organo-zeolitic material from the soils through cationic exchanges, thus limiting the negative effects $^{[4]}$. According to ${ }^{[5]}$, a very good ion exchange selectivity of clinoptilolite has been emphasized for ammonium. Immobilizing heavy metals using natural zeolites (clinoptilolite) and synthetic zeolites has been studied by $^{[6]}$. The role of the natural zeolites mixed with organic material used in growing plants from the soils polluted with heavy metals and in stabilizing the mining and metallurgical sites has been demonstrated by ${ }^{[7]}$ and

Corresponding Author: Floarea Damian, Department of Geology, North University of Baia Mare, 62/A Dr. Victor Babes Street, 430083 Baia Mare, Romania 
by ${ }^{[8]}$. The influence of the apatite and of the natural zeolites (phillipsite) in retaining heavy metals and radionuclide has been studied by ${ }^{[9]}$.

\section{MATERIALS AND METHODS}

Soils: The soil samples used in the experiment are from two contaminated sites, which are located around the mining and metallurgical complexes industries from the north-western part of the Eastern Carpathian (Baia Mare zone) and in the South part of the Western Carpathian (Romania). Both studied zones have been related with mining and metallurgical activities for several decades.

The soil samples have been prevailed from the upper soil horizons of the soil profile. The high polluted heavy metal areas are represented by different soil types: Eutricambosols (EC) in Baia Mare (BM) (Fig. 1) zone, aluviosols (AS) in Zlatna (Z) (Fig. 2) zone and entiantrosols (ET) in both zones.

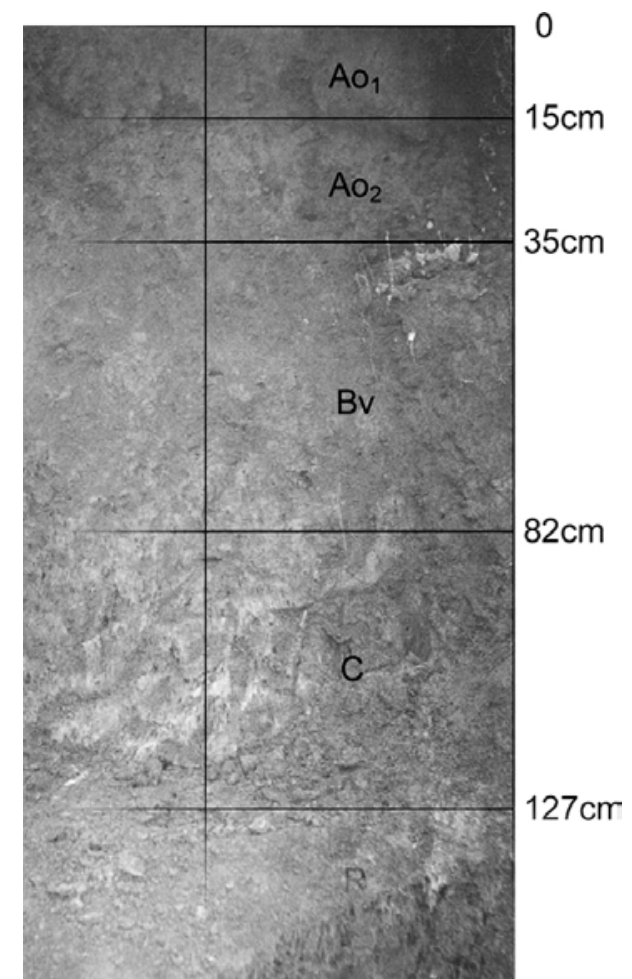

Fig. 1: Soil profile in Eutricambosol Baia Mare (ECBM).

The source of the natural zeolites: The sources of the natural zeolites, used in the experiment, are the volcanic zeolitic tuffs from the Maramures Basin, (Barsana and Sugatag). The volcanic zeolitic tuffs are related with the volcanic activity of Badenian age from the North part of Romania. At the basis of the layers there are vitroclastic and vitrocristaloclastic tuffs, compact, with a thickness between 50 and $60 \mathrm{~m}$. The occurrences of the volcaniclastic deposits from Maramures Basin described by ${ }^{[10]}$ represent an important zeolitic resource for Romania.

The zeolitic tuffs, which are the most adequate in order to reduce heavy metal pollution, are the vitroclastic ones from Barsana and Sugatag (Fig. 3) in the Maramures basin, ${ }^{[1]}$ The essential component of these zeolitic tuffs is the volcanic glass (over 90\%, sometimes over 94\%). The crystaloclasts are bellow $10 \%$ and the most common are: quartz, feldspar, and rarely hornblende and mica. The diagenetic products are present in $90-92 \%$ and are represented by: zeolites, smectites, seladonites, and carbonates. The essential characteristic of the volcanic tuffs is given by the presence of remarkable quantities of zeolitic minerals. The zeolites are represented by: clinoptilolite and only sporadically by mordenite and heulandite. The clinoptilolite appears as a devitrification product of the volcanic ash.

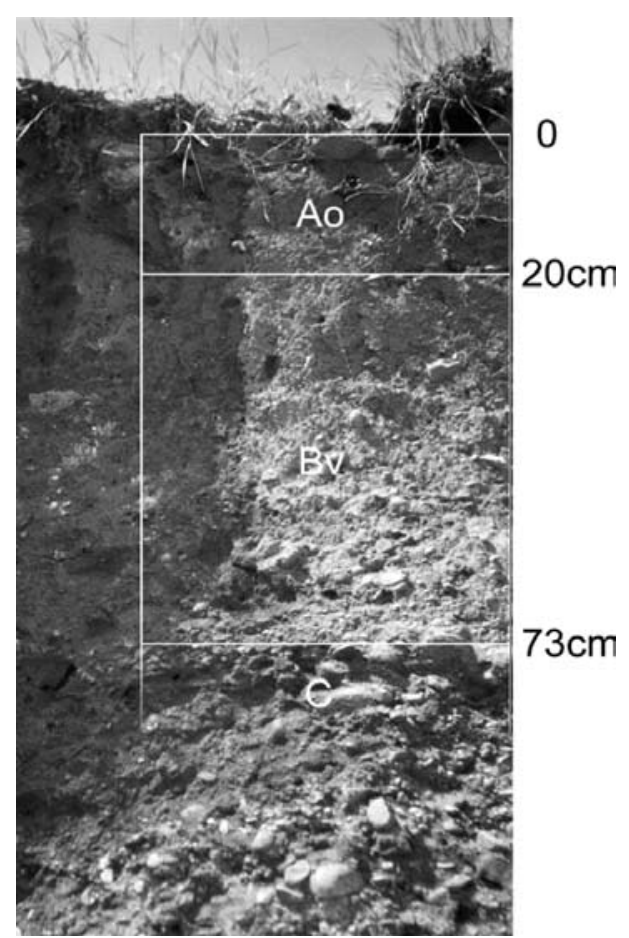

Fig. 2: Soil profile in Aluviosol Zlatna (ASZ). 


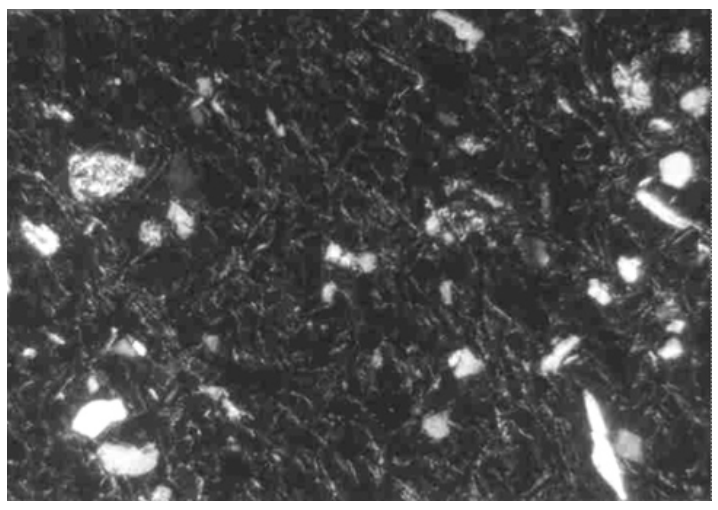

Fig. 3: Photomicrograph (crossed polarized light) illustrating zeolitized vitroclastic tuff, Sugatag, 130X.

The clinoptilolite from Sugatag and Barsana presents a diffraction spectrum with a very strong and sharp reflex of $8.9 \AA$ (Fig. 4). This demonstrates the existence of a clinoptilolite with a high level of purity, as well as an advanced level of crystallinity. The microprobe analyses identified the presence of some clinoptilolite crystals with a platy and prismatic habit of micronics size (Fig. 5). Most of the crystals are clinoptilolite, and mordenite was identified only subordinately.

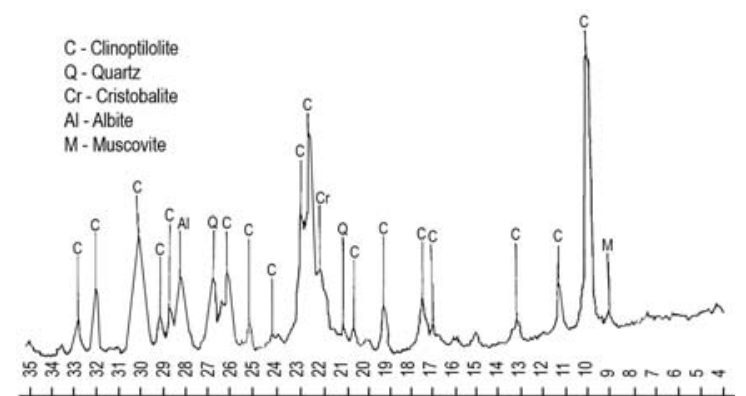

Fig. 4: X-ray diffraction spectrum of clinoptilolite.

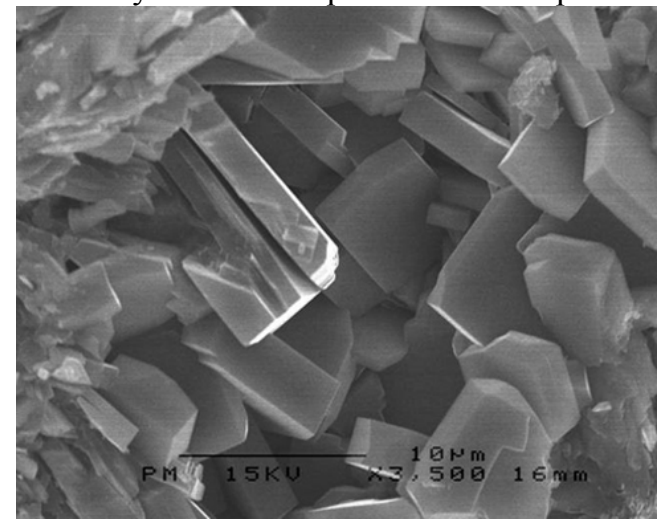

Fig. 5: SEM image of clinoptilolite crystals.

\section{OBTAINING THE ORGANO-ZEOLITIC MATERIAL}

The organo-zeolitic material used has been obtained by fermentation of $2 / 3$ fresh organic substance with $1 / 3$ zeolitic tuffs. The zeolitic tuffs were rollcrushed and ground in small grains between 0.08 and $2.5 \mathrm{~mm}$ in size, then sieved to obtain a class of $2-$ $0.5 \mathrm{~mm}$, by ${ }^{[12]}$. This material was homogeneously mixed with two parts of organic material and all was put in a plastic recipient for fermentation. The ammonium resulted from bacterial discomposure changed the zeolitic structure. In this way, the $\mathrm{Ca}^{2+}$ and $\mathrm{K}^{+}$have been included in the organic substance. This final product is excellent for inhibiting heavy metals' cations from soils and favours vegetation growth.

\section{RESULTS AND DISCUSSION}

Selection of the natural zeolitic tuffs: The processes and mechanisms that allow zeolites to remove metals from contaminated soils depend of the cationic exchange between zeolites and the compounds of the organic material. The affinity of clinoptilolite for the ammonium ion $\left(\mathrm{NH}_{4}^{+}\right)$is used to obtain the organozeolitic material.

This final product is excellent for inhibiting heavy metal cations from soils and promotes vegetation growth. In this study, there were selected the natural zeolitic tuffs that have the highest cation exchange capacity. The cation exchange capacity for the zeolitic tuffs from Barsana is: $\mathrm{Ca}^{2+}=40.34 \mathrm{meq} / \mathrm{g} ; \mathrm{Mg}^{2+}=4.67$ $\mathrm{meq} / \mathrm{g} ; \mathrm{K}^{+}=27.78 \mathrm{meq} / \mathrm{g} ; \mathrm{Na}^{+}=69.52 \mathrm{meq} / \mathrm{g}$, and for the ones from Sugatag is: $\mathrm{Ca}^{2+}=29.5 \mathrm{meq} / \mathrm{g} ; \mathrm{Mg}^{2+}=$ $4.63 \mathrm{meq} / \mathrm{g} ; \mathrm{K}^{+}=30.0 \mathrm{meq} / \mathrm{g} ; \mathrm{Na}^{+}=60.89 \mathrm{meq} / \mathrm{g}$.

The specific surface has been determined for the tuffs used in experiments. For the zeolitic tuffs from Barsana area, the specific surface values between 12.3 $20.4 \mathrm{~m}^{2} / \mathrm{g}$ with a medium of $15.85 \mathrm{~m}^{2} / \mathrm{g}$ and for the zeolitic tuffs from Sugatag is between $13.6-22.6 \mathrm{~m}^{2} / \mathrm{g}$, with a medium of $18.1 \mathrm{~m}^{2} / \mathrm{g}$. The higher values are due to some mordenite proportion, the extremely fine granulation of the zeolites and especially to the high level of clinoptilolite. The chemistry of the volcanic tuffs allowed us to observe the cations which can be changed within their structure. The variation limits of the main oxides are presented in Table 1. 
Am. J. Environ. Sci., 3 (4): 193-198, 2007

Table 1: Variation intervals for the main oxides of the zeolitic tuffs

\begin{tabular}{lccccccc}
\hline Occurrence & $\mathrm{SiO}_{2}$ & $\mathrm{Al}_{2} \mathrm{O}_{3}$ & $\mathrm{MgO}$ & $\mathrm{CaO}$ & $\mathrm{Na}_{2} \mathrm{O}$ & $\mathrm{K}_{2} \mathrm{O}$ & $\mathrm{H}_{2} \mathrm{O}^{+}$ \\
& & & & $\%$ & & & \\
Barsana & $64.80-67.80$ & $9.56-14.35$ & $0.42-1.48$ & $0.42-2.86$ & $0.57-3.53$ & $1.97-2.69$ & $4.38-9.00$ \\
Sugatag & $65.76-70.45$ & $9.13-14.38$ & $0.50-1.10$ & $1.90-3.22$ & $0.67-3.20$ & $2.00-2.90$ & $6.80-7.26$ \\
\hline
\end{tabular}

The concentration of heavy metals: The concentration of heavy metals in the studied soils is higher in the organic horizon than in the depth pedogenetical horizons. The concentration of the heavy metals reflects the influence of the physical-chemical properties (texture, $\mathrm{pH}$, humus content, cation exchange capacity, base saturation) of the soils studied, in their mobility within soil profile. The maximum content for $\mathrm{Pb}, \mathrm{Cu}$, $\mathrm{Zn}$, and $\mathrm{Cd}$ in the organic horizons for all the soils from both Baia Mare and Zlatna zones corresponds to the state of heavy metals' high pollution.

The soils used in the experiment are excessive contaminated with $\mathrm{Pb}$ in association with $\mathrm{Zn}, \mathrm{Cd}$ and $\mathrm{Cu}$ for Baia Mare zone and with $\mathrm{Cu}$ in association with $\mathrm{Zn}, \mathrm{Cd}$ and $\mathrm{Pb}$ for Zlatna zone. The concentrations of the heavy metals in the studied soils are presented in Table 2.

The chemical properties of polluted soils within the areas affected by the metallurgical activity in Baia Mare and Zlatna are presented in Table 3.

Table 2: The heavy metals concentrations in soils used in the experiment from Baia Mare and Zlatna

\begin{tabular}{ccccc}
\hline Soil type & $\mathrm{Pb}$ & $\mathrm{Cu}$ & $\mathrm{Zn}$ & $\mathrm{Cd}$ \\
\multicolumn{5}{c}{$\mathrm{mg} / \mathrm{kg}$} \\
\hline ECBM & 1054 & 37.6 & 490 & 24.2 \\
ETBM & 40375 & 409.5 & 1175 & 13.2 \\
ASZ & 50 & 360.0 & 1900 & 40 \\
ETZ & 2000 & 7000 & 3100 & 80 \\
\hline
\end{tabular}

ECBM-eutricambosol Baia Mare; ASZ-aluviosol Zlatna; ETBMentiantrosol Baia Mare; ETZ- entiantrosol Zlatna.

The soil samples used in the experiment have a lower content in nutritive elements (nitrogen phosphorus and potassium) than the fertile soils, that contain more than $0.12 \%$ nitrogen, $0.014 \% \mathrm{P}_{2} \mathrm{O}_{5}$, and $0.18 \% \mathrm{~K}_{2} \mathrm{O}$, therefore they are not fertile. After the organo-zeolitic material was added, the content in the nutritive elements was higher. We noticed a $\mathrm{pH}$ increase in the amended soil with organo-zeolitic material. The chemical properties of the soils after the organo-zeolitic material was added are presented in Table 4.

The growth of the plants: After mixing the soil with the organo-zeolitic material, there have been made 5 experimentation variants, one for each soil type in Baia
Mare zone and 4 experimentation variants for each soil type from Zlatna zone. These variants are:- (Baia Mare): 1 and 5-original soil, 2 and 6-soil mixed with organo-zeolite (17\%), 3 and 7- soil mixed with organozeolite (17\%) and lime, 4 and 8-soil mixed with lime, 9 and 10-soil mixed with organo-zeolite (33\%) and lime;(Zlatna): 1 and 5-original soil, 2 and 6-soil mixed with organo-zeolite 17\%, 3 and 7- soil mixed with organozeolite and lime, 4 and 8- soil mixed with lime. The original polluted soil and the treated soil have been planted with Lolium perenne.

The growth of the plants has demonstrated that the soil treated with organo-zeolitic material allows the growth of vegetation much faster than the original soil or in soil treated with lime, (Fig.6). In the treated soil, the germination for the (ETBM and ECBM), was accomplished in proportion of $90 \%$ and approximately $40 \%$ in the original soil.

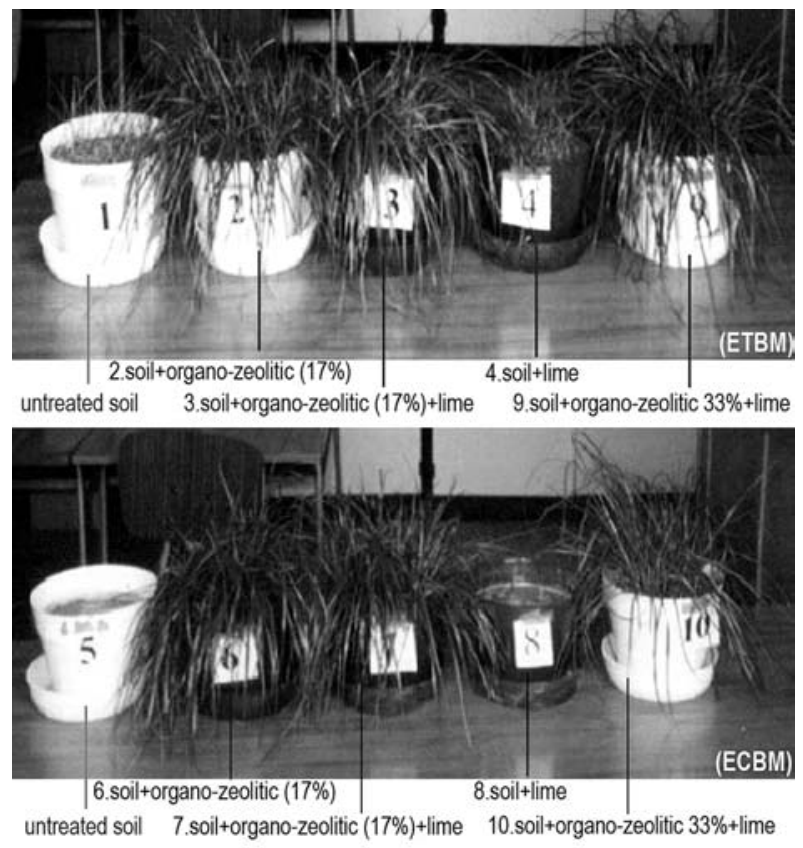

Fig. 6: The vegetation growth for different types of experimentation (about 42 days) in the soils from Baia Mare; ECBM-eutricambosol Baia Mare ETBM-entiantrosol Baia Mare. 
Am. J. Environ. Sci., 3 (4): 193-198, 2007

Table 3: Chemical properties of polluted soils from Baia Mare and Zlatna

\begin{tabular}{rcccccccccccc}
\hline $\begin{array}{c}\text { Soil } \\
\text { type }\end{array}$ & $\mathrm{pH}$ & $\begin{array}{c}\text { Humus } \\
\%\end{array}$ & $\mathrm{Al}$ & \multicolumn{2}{c}{$\mathrm{CEC}$} & $\mathrm{SB}$ & $\mathrm{Ah}$ & $\mathrm{V}$ Ah & $\mathrm{Nt}$ & $\mathrm{P}$ & $\mathrm{K}$ \\
ECBM & 4.4 & 0.33 & 6.35 & 31.33 & 15.38 & 15.95 & 49.09 & 0.048 & 10 & 85 \\
ETBM & 4.1 & 0.28 & 12.45 & 42.16 & 4.51 & 37.65 & 10.69 & 0.030 & 12 & 60 \\
ASZ & 5.0 & 1.56 & 43 & 21.96 & 20.51 & 1.45 & 93.40 & 0.128 & 1.1 & 72 \\
ETZ & 4.0 & 1.44 & 27 & 16.93 & 5.90 & 11.03 & 27.50 & 0.09 & 17.4 & 115 \\
\hline
\end{tabular}

ECBM-eutricambosol Baia Mare; ASZ-aluviosol Zlatna; ETBM-entiantrosol Baia Mare; ETZ- entiantrosol Zlatna); CEC-Cation Exchange Capacity; SB- total basic cation; Ah- hydrolytic acidity; $\mathrm{V}_{\mathrm{Ah}}$ - base saturation ratio; $\mathrm{Al}$-soluble aluminium.

Table 4: Chemical properties of the amended soil with organo-zeolitic material

\begin{tabular}{|c|c|c|c|c|c|c|c|c|c|c|}
\hline $\begin{array}{l}\text { Soil } \\
\text { type }\end{array}$ & $\mathrm{pH}$ & $\begin{array}{c}\text { Humus } \\
\%\end{array}$ & $\mathrm{Al}$ & \multicolumn{2}{|c|}{$\mathrm{mg} / 100 \mathrm{~g} / \mathrm{soil}$} & $\mathrm{Ah}$ & \multicolumn{2}{|c|}{$\%$} & $P$ & $\mathrm{~K}$ \\
\hline ECBM & 5.6 & 1.52 & 0.65 & 39.92 & 28.72 & 11.20 & 71.94 & 0.10 & 580 & 720 \\
\hline ETBM & 5.5 & 0.46 & 4.59 & 62.50 & 17.43 & 45.07 & 27.88 & 0.11 & 460 & 760 \\
\hline ASZ & 5.5 & 2.49 & 15.75 & 38.66 & 36.92 & 1.74 & 97.70 & 0.25 & 374 & 256 \\
\hline ETZ & 5.0 & 2.40 & 9.74 & 35.65 & 22.42 & 13.23 & 56.37 & 0.18 & 372 & 249 \\
\hline
\end{tabular}

ECBM-eutricambosol Baia Mare; ASZ-aluviosol Zlatna; ETBM-entiantrosol Baia Mare; ETZ- entiantrosol Zlatna); CEC-Cation Exchange Capacity; SB- total basic cation; Ah- hydrolytic acidity; $\mathrm{V}_{\mathrm{Ah}}$ - base saturation ratio; Al-soluble aluminium.

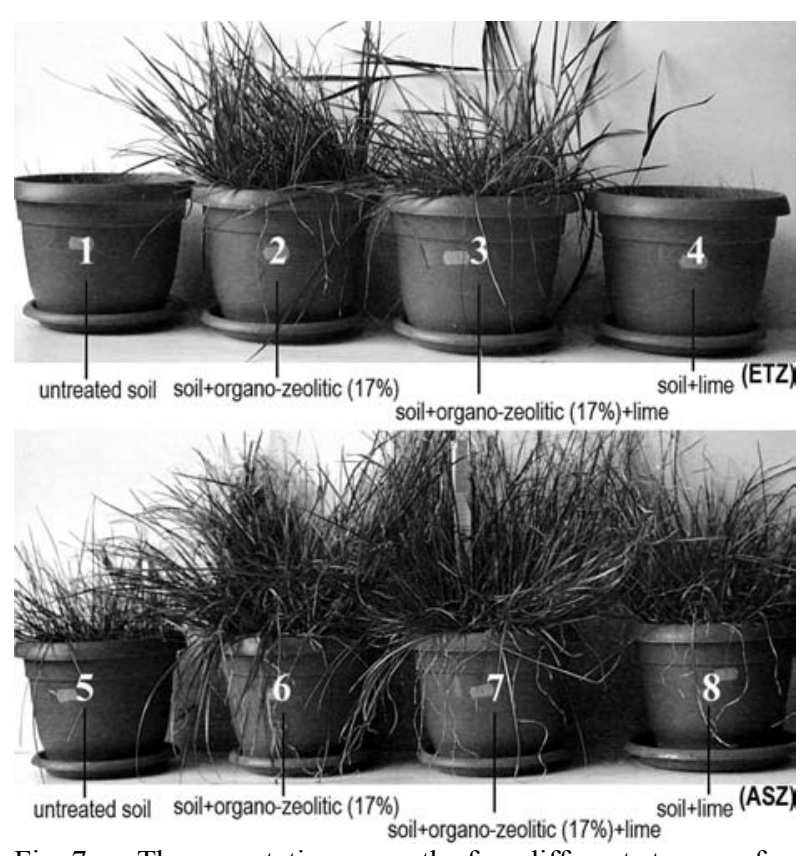

Fig. 7: The vegetation growth for different types of experimentation (about 90 days) in the soils from Zlatna; ASZ-aluviosol Zlatna; ETZ- entiantrosol Zlatna)

In the ETZ-entiantrosol from Zlatna and AVZ, the germination was accomplished in proportion of $60-75 \%$ for the treated soil and $30-40 \%$ in the original one. In the treated soils, the height of the grass, is about $30-40 \mathrm{~cm}$ in the treated soil after 90 days of vegetation, (Fig.7).

\section{CONCLUSIONS}

Considering the results obtained during the experiment, we can conclude that the maximum plant growth was accomplished in the cases when the soil was treated with organo-zeolitic material. During the growth, the plants take from the soil solution $\mathrm{NH}_{4}{ }^{+}$ and some cations. The cations and $\mathrm{NH}_{4}{ }^{+}$taken by the plants are filled in the soil solution from the structure of the organo-zeolitic material. In the same way, the cations and $\mathrm{NH}_{4}^{+}$ions included in the zeolitic structure are exchanged with the heavy metal cations, which are fixed in the zeolitic structure. Similar data about the structural equilibrium of the heavy metals cations in natural zeolites ${ }^{[4]}$ have observed a good selectivity of the clinoptilolite for lead. The cationic exchange is adjusted by the growing plants, which create a permanent $\mathrm{NH}_{4}^{+}$cation deficiency in the soil solution.

This growth was possible because the organozeolitic material mixed with the soil provides the substances needed by the plants to develop (ammonium, humus, potassium, calcium). At the same time, the heavy metals that inhibit the plant development are blocked through the cationic exchange mechanism that makes them enter the zeolites structure and they no longer have direct access to the plant roots. This method is less expensive than soil detoxification by using other technologies. 


\section{ACKNOWLEDGMENT}

This research has been supported by financial resources within the 5GR code 138 Grant, financed by the National Council of the Scientific Research from the Ministry of Education in Romania.

\section{REFERENCES}

1. Mumpton, F. A., 1973. Worldwide Deposits and Utilization of Natural zeolites, Industrial Minerals, 73, 2, p. 30-45.

2. Mumpton, F. A., 1999. La roca magica: Uses of natural zeolites in agriculture and industry. Proc. Natl. Acad. Sci. USA, Vol. 96. pg. 3463-3470, March 1999.

3. Ming, D. W., and F. A. Mumpton, 1995. Natural Zeolites '93: Occurrence, properties, use, Int. Commission on Natural Zeolites, Brockport, NY.

4. Colella C., 1996. Ion exchange equilibria in zeolite minerals, Mineral. Deposita 31, pg. $554-562$. 5. Leggo, P. J., 2000. An investigation of plant growth in an organo-zeolitic substrate and its ecological significance, Plant and soil, 219, pg. 135 146.

6. Oste, L. A., Lexmond, Theo M. and W. H. Van Riemsdijk, 2002. Metal Immobilization in Soils using Synthetic Zeolites. Journal of Environmental Quality 31:813-821.
7. Leggo, P. J. and Ledésert, B., 2001. Use of an organo-zeolitic fertilizer to sustain plant growth and stabilize metallurgical and mine-waste sites. Mineralogical Magazine, Vol. 65(5), 563-570.

8. Leggo, P. J. and Ledésert, B., and Christie, G., 2006. The role of clinoptilolite in organo-zeolitic soil systems used for phytoremediation. Science of the Total Environment, 363(2006) 1-10.

9. Knox, A.S., Kaplan, D.I., Adriano, D.C., Hinton, T.G. and M. D. Wilson, 2003. Apatite and Phillipsite as Sequestering Agents for Metals and Radionuclides. Journal of Environmental Quality 32:515-525.

10. Cochemé J. J., Leggo P. J., Damian Gh., Ledesert B., Fulop A. \& Grauby O., 2003. The mineralogy and distribution of zeolitic tuffs of the Maramures basin, Romania. Clays and Clay Minerals Vol. 51, nr. 6, p. 599-608.

11. Damian Gh., Pop N. Kovacs P. P., 1991. La pétrologie des tufs volcaniques badéniene du Bassin MaramureS, in The Volcanic Tuffs from the Transylvanian Basin, Cluj Napoca pg. 233 - 243.

12. Ibrahim K. M., Inglethorpe S. D. J., 1996. Mineral processing characteristics of natural zeolites from the Aritayn Formation of northeast Jordan, Min. Deposita 31, pg $589-596$. 